\title{
Pretreatment of biomass by torrefaction
}

\author{
WANG GuiJun, LUO YongHao*, DENG Jian, KUANG JiangHong \& ZHANG YunLiang
}

School of Mechanical Engineering, Shanghai Jiao Tong University, Shanghai 200240, China

Received October 29, 2010; accepted January 9, 2011

\begin{abstract}
Agricultural biomass has some drawbacks such as high moisture content, low energy density and wide distribution and as a result, the cost of transport and storage are high. Moreover, raw biomass has poor grindability so its use in a pulverized boiler or entrained flow gasifier is difficult. Torrefaction is a mild pyrolysis process carried out at temperatures ranging from $200^{\circ} \mathrm{C}$ to $300^{\circ} \mathrm{C}$ to deal with these problems. The cotton stalk and wheat straw were torrefied in a fix-bed reactor at moderate temperatures $\left(200^{\circ} \mathrm{C}\right.$, $230^{\circ} \mathrm{C}, 250^{\circ} \mathrm{C}, 270^{\circ} \mathrm{C}$ and $300^{\circ} \mathrm{C}$ ) under $\mathrm{N}_{2}$ for $30 \mathrm{~min}$. The biomass chars after torrefaction had higher energy density and improved grindability characteristics compared with raw biomass and they also showed hydrophobic characteristics. The volatiles consist of a condensable fraction and a non-condensable fraction. The former mainly contained water and tar (organic products but mainly acetic acid). The non-condensable products are typically comprised of $\mathrm{CO}_{2}, \mathrm{CO}$ and a small amount of $\mathrm{CH}_{4}$ and even trace $\mathrm{H}_{2}$. The volatiles increased with an increase in the torrefaction temperature but the solid yield and the energy yield decreased. However, the grindability and energy density of the biomass char showed great improvement. A kinetic study on the generation of the main non-condensable gases was undertaken and we conclude that the gases are formed by parallel independent first-order reactions. Characteristic kinetic parameters for the generation of each gas were determined.
\end{abstract}

agricultural biomass, torrefaction, pretreatment, grindability, kinetics

Citation: Wang G J, Luo Y H, Deng J, et al. Pretreatment of biomass by torrefaction. Chinese Sci Bull, 2011, 56: 1442-1448, doi: 10.1007/s11434-010-4143-y

As a source of green energy, biomass generates less $\mathrm{SO}_{2}$ and $\mathrm{NO}_{x}$, and the emission of other gases is negligible and importantly it is $\mathrm{CO}_{2}$ neutral. However, biomass has some drawbacks such as high moisture content, hydroscopic nature, low energy density, difficult for storage, production dependent on seasonal variation and wide distribution $[1,2]$, which makes it unsuitable for large-scale use. Therefore, plenty of research has focused on the conversion of low-grade biomass into high quality energy. Torrefaction is an effective chemical pretreatment to deal with biomass. After torrefaction, the solid biomass products have a smaller volume and higher energy density than untreated biomass and, therefore, the cost of storage and transportation can be reduced. If the solid products are pressed into briquettes their energy density can be further enhanced. With increased grindability of the solid products that compose the biomass, this fuel may be used on large scale in a pulverized

*Corresponding author (email: yhluo@sjtu.edu.cn) boiler or an entrained flow gasifier [3].

Torrefaction is a mild pyrolysis treatment that involves heating the biomass at moderate temperatures between $200^{\circ} \mathrm{C}$ and $300^{\circ} \mathrm{C}$ under an inert atmosphere. During this process, most of the water and some light volatiles are removed from the biomass. Prins et al. [4-6] undertook comprehensive studies on pyrolysis kinetics and characteristics of the pyrolysis products of willow, straw and larch using thermogravimetry and a semi-industrial scale bench at 230-300 ${ }^{\circ}$ C. Saravanakumar et al. [7] studied the conversion of wood by pyrolysis to charcoal in a partial combustion kiln (under different conditions) to understand the influence of moisture content, type and size during charcoal generation, the main reactions at different temperature and the characteristics of carbocoal. Felfli et al. [8] studied the torrefaction of wood briquettes from $220-270^{\circ} \mathrm{C}$ and their results show that the solid products have good hydrophobicity. According to the energy yield, the most suitable temperature for torrefaction was found to be between 250 and 
$270^{\circ} \mathrm{C}$. Finally, a technical and economic feasibility analysis about the torrefaction of wood briquettes under Brazilian national conditions has been reported [9]. Arias studied the grindability and reactivity of the solid products of wood torrefaction from $240-280^{\circ} \mathrm{C}$ and compared them to raw materials, and kinetic parameters were calculated [1]. Jiang et al. [10] studied the effects of temperature and residence time on the solid state product's calorific value, quality and energy yield after torrefaction of a wood block, sawdust and a rice husk extrusion bar. Their results show that torrefaction is optimum at a temperature of $280^{\circ} \mathrm{C}$. Zhang et al. [2] studied the effect of rice straw torrefaction at $300-550^{\circ} \mathrm{C}$ on the quality of the resultant semi-coke and the energy yield. Entrained flow gasification results for biomass and charcoal were compared based on ASPEN PLUS software and the results show that entrained flow gasification is ideal at a torrefaction temperature of $400^{\circ} \mathrm{C}$. To find a relationship between biomass torrefaction and energy density, grindability and overall gasification efficiency, Zhao et al. [11] carried out torrefaction experiments in a lab-scale reactor with four kinds of biomass (rice husk, Korean pine, pinus sylvestris, ashtree) as a feedstock between $230^{\circ} \mathrm{C}$ and $290^{\circ} \mathrm{C}$. Their results show that at a torrefaction temperature of $250^{\circ} \mathrm{C}$ the torrefied biomass has a better mass and energy yield.

Agricultural biomass is different to woody biomass because crops have a higher hemicellulose content that decomposes more easily when heated. We conducted torrefaction experiments in a fixed bed reactor with cotton stalk and wheat straw at $200^{\circ} \mathrm{C}, 250^{\circ} \mathrm{C}$ and $300^{\circ} \mathrm{C}$ to determine the distribution of the pyrolysis products. We were especially interested in the pattern of gas release, which made up about $60 \%$ of the total volatile products. By comparing the particle distribution of solid products and raw biomass that were ground under the same conditions, it is found that the torrefied biomass had better grindability. At higher temperature, the energy yield of cotton stalk reduced dramatically but wheat straw showed a moderate trend. A kinetic analysis of $\mathrm{CO}_{2}$ and $\mathrm{CO}$ generation from cotton stalk and wheat straw showed that they have a similar $\mathrm{CO}$ generation activation energy while the $\mathrm{CO}_{2}$ generation activation energy of wheat straw is far higher than that of cotton stalk.

\section{Experimental}

\subsection{Materials}

Two kinds of typical agricultural biomass (cotton stalk and wheat straw) were collected from Wuwei County in Anhui Province. The raw material was cut into pieces to give an average length of $25 \mathrm{~mm}$. It was then dried using an air-blower-driver drying closet at $95^{\circ} \mathrm{C}$ over about $24 \mathrm{~h}$ and the material was stored in sealed bags. The proximate and ultimate analysis of the cotton stalk and wheat straw is listed in Table 1.

\subsection{Experimental equipment and procedures}

The pyrolysis experiments were carried out in a vertical fixed bed furnace (Figure 1). An alundum tube with a diameter of $60 \mathrm{~mm}$ and a length of $500 \mathrm{~mm}$ was used. Silicon carbide rods with a length of $200 \mathrm{~mm}$ were arranged in the middle of the alundum tube for heating. Samples were placed on a grate, which was $200 \mathrm{~mm}$ above the bottom of the alundum tube. Two thermocouples $150 \mathrm{~mm}$ apart were arranged outside the tube for temperature measurement and automatic control. As a protective gas, nitrogen was piped from the bottom of alundum tube and then carried the reaction products out of the pyrolysis zone through the grate and discharged them out of the stainless steel outlet pipe on top of the fixed bed furnace. The outlet pipe was fitted with a heating device to ensure that the temperature was no less than $200^{\circ} \mathrm{C}$ to prevent tar and other liquid products from condensing before entering the condensation unit. Condensable volatiles were trapped by a two-mouth flask immersed in liquid nitrogen. After filtration, small particles and not condensed gases passed into an infrared multi-gas analyzer, Gasboard-5 (Wuhan Sifang). The analyzer showed a real-time display of the percentage of $\mathrm{CO}, \mathrm{CO}_{2}, \mathrm{H}_{2}, \mathrm{CH}_{4}$, $\mathrm{O}_{2}$ and the data was automatically recorded and saved by a computer. The raw biomass and torrefied samples were ground using a Corey KER-1/100A sealed pulverizer and then screened with a sieve for weighing. The calorific value of the charcoal was measured using an intelligent calorimeter (Hebi Huatong ZDHW-6 type).

Samples of $22 \pm 0.1 \mathrm{~g}$ were taken from the grate and then the joints of entrance and exit of the furnace was sealed by high-temperature resistance glue. A high flow of high-purity nitrogen gas was then used to purge the bottom of the furnace to remove any air from the alundum tube. When the concentration of oxygen dropped to $0.5 \%$, the gas inlet valve was regulated to ensure the flow of nitrogen gas was maintained at $500 \mathrm{~mL} / \mathrm{min}$. The heating device was then turned on and the samples were heated from room temperature to the target temperature of $100^{\circ} \mathrm{C}$ at a heating rate of $30^{\circ} \mathrm{C} / \mathrm{min}$ and kept at this temperature for $10 \mathrm{~min}$. The thermocouples recorded the heating area temperature. The

Table 1 Proximate and ultimate analysis of the investigated biomass (ad)

\begin{tabular}{|c|c|c|c|c|c|c|c|c|c|c|}
\hline \multirow{2}{*}{ Sample } & \multicolumn{4}{|c|}{ Proximate analysis (\%) } & \multirow{2}{*}{ LHV $\left(\mathrm{MJ} \mathrm{kg}^{-1}\right)$} & \multicolumn{5}{|c|}{ Ultimate analysis (\%) } \\
\hline & $M$ & $V$ & $F C$ & $A$ & & $\mathrm{C}$ & $\mathrm{H}$ & $\mathrm{O}$ & $\mathrm{N}$ & $S$ \\
\hline Cotton stalk & 1.19 & 76.92 & 19.19 & 2.70 & 19.32 & 46.43 & 6.18 & 42.62 & 0.80 & 0.08 \\
\hline Wheat straw & 3.30 & 71.59 & 18.73 & 6.38 & 17.81 & 43.00 & 5.36 & 41.11 & 0.63 & 0.22 \\
\hline
\end{tabular}




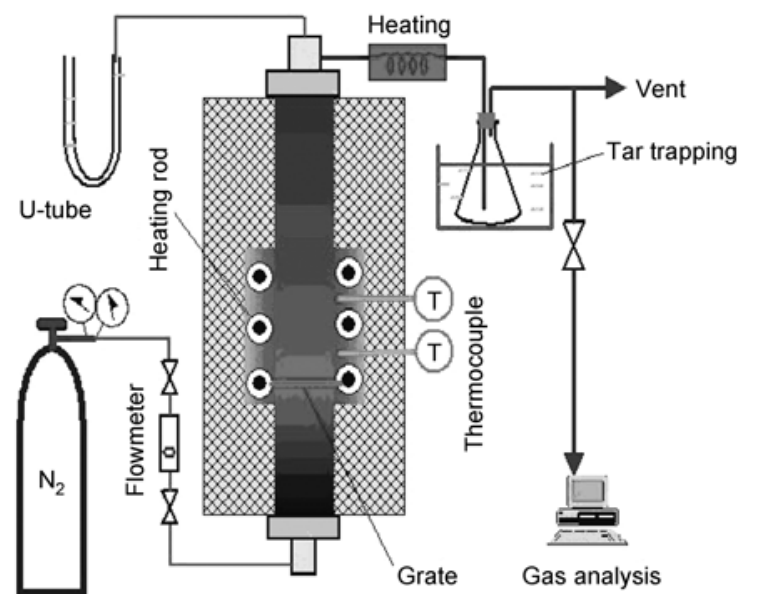

Figure 1 Fixed bed reactor.

final temperatures were set to either $200^{\circ} \mathrm{C}, 230^{\circ} \mathrm{C}, 250^{\circ} \mathrm{C}$, $270^{\circ} \mathrm{C}$ or $300^{\circ} \mathrm{C}$ (we only obtained the solid product yield and HHV measurements) at the same heating rate and the samples were kept at this temperature for $30 \mathrm{~min}$. Finally, the heating device was turned off but the nitrogen gas was maintained until the furnace temperature was below $110^{\circ} \mathrm{C}$ upon which the sample was removed. The solid and liquid products were then weighed. This experiment was repeated three times for each sample and the average value of the three experiments is reported. Each sample was ground for $5 \mathrm{~min}$ and then they were passed through three different size sieves $(100 \mu \mathrm{m}, 150 \mu \mathrm{m}, 450 \mu \mathrm{m})$ for screening and weighing.

To determine the total volatiles ratio at specific temperatures, we also conducted experiments at corresponding temperatures until the gas concentration was less than $0.1 \%$.

\section{Results and analysis}

\subsection{Product distribution}

After torrefaction at $200^{\circ} \mathrm{C}, 250^{\circ} \mathrm{C}$ and $300^{\circ} \mathrm{C}$, the products contained solid charcoal, a liquid ingredient (water and tar) and gases (mainly $\mathrm{CO}_{2}$ and $\mathrm{CO}$ ). The weight percentage of the torrefaction products is shown in Table 2. The sum of the liquid and gas products corresponds to the weight loss through torrefaction, and this is known as biomass conversion efficiency. The conversion efficiency indicates the effect of the torrefaction process on the raw materials. It is related to the size of the raw biomass and the torrefaction conditions. As the torrefaction temperature increased, the conversion rate of the two samples also increased. The yield of solid product decreased but the yield of liquid and gas components increased. During biomass pyrolysis, hemicellulose decomposes between $200^{\circ} \mathrm{C}$ and $250^{\circ} \mathrm{C}$ and cellulose decomposes between $240^{\circ} \mathrm{C}$ and $350^{\circ} \mathrm{C}$ while lignin decomposes between $280^{\circ} \mathrm{C}$ and $500^{\circ} \mathrm{C}$ and over longer time
[12]. The biomass pyrolysis products are closely related to temperature and heating rate. At higher temperatures, more gas is produced because of secondary reactions and tar decomposition but slow pyrolysis favors the formation of solid coke while fast pyrolysis increases the tar yield. The mechanism of biomass pyrolysis is shown in Figure 2.

The torrefaction of biomass is mainly composed of hemicellulose pyrolysis with a partial decomposition of cellulose and lignin. Between $200^{\circ} \mathrm{C}$ and $300^{\circ} \mathrm{C}$ xylan hemicellulose undergoes dehydration, dehydroxylation and deacetylation reactions. Hemicellulose thermal decomposition products are mainly gases and liquids [5] and at lower temperatures dehydration reactions has a major role in the release of volatiles and the formation of solid products. At higher temperatures, the decomposition of L-glucan will have a major role. The increase in water content results from water evaporation from the sample and also from the dehydration of organic molecules. After torrefaction, the stalk will have lost most of its water while some low molecular weight volatile organic compounds and long-chain polysaccharides decompose. Lignin pyrolysis produces mainly charcoal [13].

At higher temperature, the solid products gradually change color from brown to black and the apparent volume reduces significantly. Additionally, the solid products become brittle, fragile and cylindrical or spherical in shape. As the solid products lose most of their moisture and their volatile matter, their energy density increases and the charcoal even has a hydrophobic character $[5,8,13]$.

The brown liquid products have an irritating smell and this is mainly composed of water, acetic acid and a small amount of methanol, lactic acid and furfural. [5,13]. As the pyrolysis temperature increases, the liquid product yield increases and it has a darker color. The liquid mainly comes from the decomposition of hemicellulose [11] and the liquid product yield is very small at $200^{\circ} \mathrm{C}$ of which water accounts for a large proportion. Water is released in the form of evaporation (mainly below $150^{\circ} \mathrm{C}$ ) followed by dehydra-

Table 2 Distribution of the torrefied biomass products

\begin{tabular}{cccccc}
\hline Sample & $\begin{array}{c}\text { Temperature } \\
\left({ }^{\circ} \mathrm{C}\right)\end{array}$ & $\begin{array}{c}\text { Solid yield } \\
(\mathrm{wt} \%)\end{array}$ & $\begin{array}{c}\text { Liquid yield } \\
(\mathrm{wt} \%)\end{array}$ & $\begin{array}{c}\text { Gas yield } \\
(\mathrm{wt} \%)\end{array}$ & $\begin{array}{c}\text { Conversion } \\
(\%)\end{array}$ \\
\hline \multirow{2}{*}{ Cotton } & 200 & 63.89 & 4.14 & 31.97 & 36.11 \\
stalk & 250 & 33.8 & 13.8 & 52.4 & 66.2 \\
& 300 & 30.04 & 17.28 & 52.68 & 69.96 \\
\multirow{4}{*}{ Wheat } & 200 & 47.56 & 3.93 & 48.51 & 52.44 \\
straw & 250 & 41.24 & 9.69 & 49.07 & 58.76 \\
& 300 & 31.61 & 11.57 & 56.82 & 68.39 \\
\hline
\end{tabular}

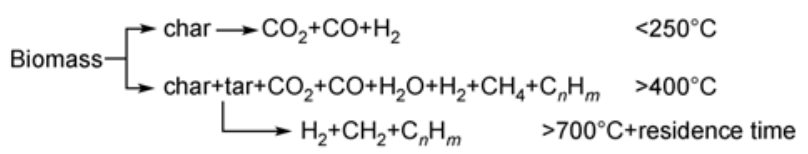

Figure 2 Mechanism of biomass pyrolysis. 


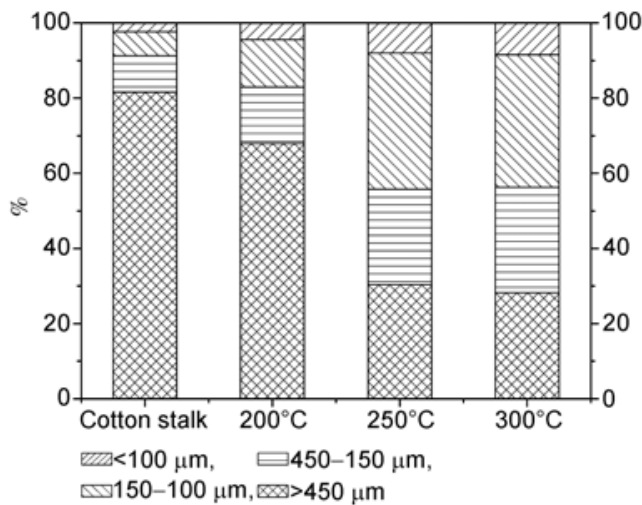

(a)

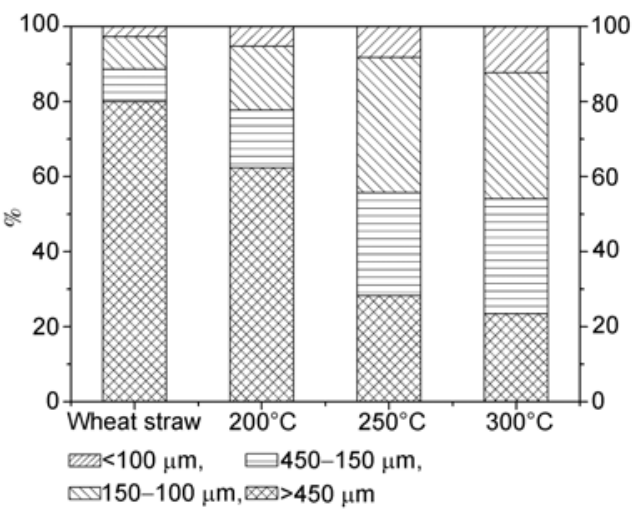

(b)

Figure 3 Grindability of the original straw and char. (a) Cotton stalk, (b) wheat straw.

tion and depolymerization. As the temperature increases to $250^{\circ} \mathrm{C}$ and $300^{\circ} \mathrm{C}$, the hydroxyl groups in hemicellulose easily form intra- and intermolecular hydrogen bonds to eventually form water. Simultaneous decarboxylation, glycosidic bond breaking, C-O bond breaking, C-C bond breaking and the formation of a series of acids, alcohols, aldehydes, ethers such as tar substances, and $\mathrm{CO}, \mathrm{CO}_{2}, \mathrm{CH}_{4}$ and other gas compounds have been reported [14].

\subsection{Grindability and energy yield}

The grindability of the raw biomass and torrefied biomass is shown in Figure 3. After milling, about $80 \%$ of the raw biomass particles had diameters larger than $450 \mu \mathrm{m}$ and about $10 \%$ were smaller than $150 \mu \mathrm{m}$. After torrefaction, the grindability of the solid products improved greatly. After torrefied at $200^{\circ} \mathrm{C}, 70 \%$ of the solid products were larger than $450 \mu \mathrm{m}$ and $20 \%$ were smaller than $150 \mu \mathrm{m}$. When torrefied at $250^{\circ} \mathrm{C}, 30 \%$ of the ground particles were larger than $450 \mu \mathrm{m}$ while $40 \%$ of the particles were smaller than $150 \mu \mathrm{m}$. The grindability of the solid product torrefied at $300^{\circ} \mathrm{C}$ almost has the same characteristics as that torrefied at $250^{\circ} \mathrm{C}$.

Torrefaction has a large effect on the strength of the cell wall in biomass material. The microfibrils which aggregate into very long strands by polysaccharides are enclosed in a continuous system of amorphous lignin. By decomposing hemicellulose in the torrefaction process, the orientation of the microfibrils in the lignin matrix may change, which influences the viscoelastic properties of the biomass [6]. Arias [1] investigated raw biomass and torrefied biomass by optical microscopy and found that after pyrolysis, the fibers between the biomass particles were broken and the decrease in biomass particle size is mainly because of the reduction in length and the change to spherical geometry.

After torrefaction, the physical form of the biomass charcoal changed as it reduced significantly in size, the color became dark brown or black and the weight decreased.
The carbon content increases and the oxygen as well as the hydrogen content decreases in the charcoal because the process of pyrolysis releases water, $\mathrm{CO}_{2}$ and other volatile matter; therefore, the calorific value of the charcoal increases significantly [2]. The HHV of charcoal is shown in Table 3. Under the same conditions, the calorific value of wheat straw charcoal was increased but the value was lower than which of cotton stalk charcoal that mainly because wheat straw has a higher ash content than cotton stalk.

The energy density is reflected in the energy per unit charcoal which results from torrefaction. The weight loss during the process also needs to be considered. The energy yield reflects the magnitude of energy conversion of the biomass during the torrefaction process. This will be beneficial for a reasonable assessment of the pretreatment process. The energy yield was calculated as follows:

$$
y_{\text {energy }}=\frac{m_{\text {char }}}{m_{0}} \frac{\mathrm{HHV}_{\text {char }}}{\mathrm{HHV}_{0}} \times 100 \%,
$$

where $m$ is the weight, $\mathrm{HHV}_{0}$ and $\mathrm{HHV}_{\text {char }}$ are the calorific values of the original straw and the charcoal, respectively. The energy yield of the solid charcoal is shown in Figure 4. Both kinds of biomass generally have a high energy yield at $200^{\circ} \mathrm{C}$. At higher temperatures, the energy yield decreases. As the pyrolysis temperature increases from $200^{\circ} \mathrm{C}$ to $230^{\circ} \mathrm{C}$ and to $250^{\circ} \mathrm{C}$, the energy yield of cotton stalk de-

Table 3 Proximate analysis of the solid product

\begin{tabular}{cccccc}
\hline $\begin{array}{c}\text { Sample-temperature } \\
\left({ }^{\circ} \mathrm{C}\right)\end{array}$ & $M(\%)$ & $V(\%)$ & $F C(\%)$ & $A(\%)$ & $\begin{array}{c}\mathrm{HHV} \\
\left(\mathrm{MJ} \mathrm{kg}^{-1}\right)\end{array}$ \\
\hline Cotton stalk -200 & 5.24 & 44.43 & 41.89 & 8.44 & 23.94 \\
Cotton stalk -250 & 6.7 & 36.13 & 44.48 & 12.69 & 24.57 \\
Cotton stalk -300 & 6.1 & 31.16 & 48.0 & 14.74 & 25.03 \\
Wheat straw -200 & 6.51 & 39.01 & 38.98 & 15.5 & 19.84 \\
Wheat straw -250 & 4.83 & 28.21 & 43.66 & 23.3 & 20.85 \\
Wheat straw -300 & 4.78 & 14.84 & 55.43 & 24.95 & 21.67 \\
\hline
\end{tabular}




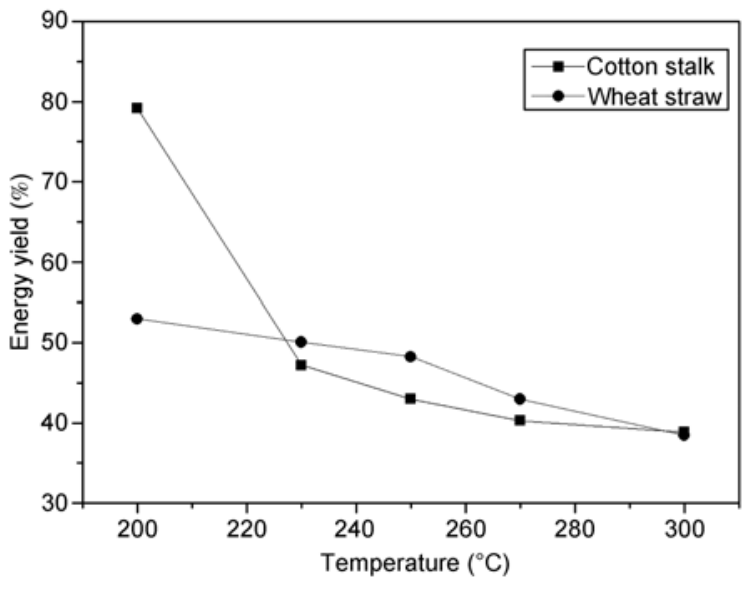

Figure 4 Energy yield of solid charcoal under different temperature.

creases rapidly from $79 \%$ to $47 \%$ and to $42 \%$, respectively. At $270^{\circ} \mathrm{C}$ and $300^{\circ} \mathrm{C}$, the percentage decreases slightly to $40.3 \%$ and $38.9 \%$, respectively. The energy yield of the wheat straw did not change as dramatic as that of the cotton stalk. The energy yield for the five examined operating conditions were: $53 \%, 50.1 \%, 48.3 \%, 43 \%$ and $38.5 \%$. At $250^{\circ} \mathrm{C}$, the main reaction is hemicellulose pyrolysis [1]. Compared with wood biomass under similar conditions $[10,11]$ the energy yield of the agricultural biomass is substantially lower because agriculture biomass has higher hemicellulose content than wood biomass. The results show that a higher torrefaction temperature results in a lower energy yield. To obtain a higher energy yield for agricultural biomass the temperature should not exceed $250^{\circ} \mathrm{C}$

\subsection{Generation law for gas products}

(i) Gas products. The gas products formed are mainly $\mathrm{CO}_{2}$, $\mathrm{CO}$, small amounts of $\mathrm{CH}_{4}$ and even traces of $\mathrm{H}_{2}$. The gas mainly comes from the decomposition of hemicellulose [5,14], combined water release between $100-180^{\circ} \mathrm{C}$ and the generation of $\mathrm{CO}, \mathrm{CO}_{2}$ and condensable volatiles between $180^{\circ} \mathrm{C}$ and $270^{\circ} \mathrm{C}$ [7]. A law for the gas products for the two samples under different conditions is shown in Figure 5. The concentration of the gas components follows the order: $\mathrm{CO}_{2}, \mathrm{CO}, \mathrm{CH}_{4}$ and with the pyrolysis temperature increases the gas concentration and the cumulative amount of released gas for both wheat straw and cotton stalk ware increased. Gas release occurred earlier in the reaction for cotton stalk than for wheat straw and the gas yield of cotton stalk was larger. This is because the volatile content of cotton stalk (76.92\%) is higher than that of wheat straw (71.59\%). Xylan hemicellulose begins to pyrolyze at about $200^{\circ} \mathrm{C}$ while lignin and cellulose start pyrolysis at about $250^{\circ} \mathrm{C}$. At lower temperatures, the generation of $\mathrm{CO}, \mathrm{CO}_{2}$ and $\mathrm{H}_{2} \mathrm{O}$ is because of hemicellulose and cellulose decomposition while dehydroxylation $(-\mathrm{COOH})$ has a crucial role in the produc- tion of oxygen-containing gas.

The dehydration and dehydroxylation reactions of hemicellulose resulting in water and $\mathrm{CO}_{2}$ makes up a large part of the volatile products so the $\mathrm{O} / \mathrm{C}$ ratio of charcoal is greatly reduced. A lower $\mathrm{O} / \mathrm{C}$ ratio indicates a higher gasification efficiency. Because of water removal as well as $\mathrm{CO}_{2}$ and $\mathrm{CO}$ gas release, the $\mathrm{C} / \mathrm{O}$ ratio of charcoal increases and the energy density of charcoal improves [8].

(ii) Gas generation kinetic parameters. For the torrefaction process, gas generation is considered to be a group of independent first reactions and every gas has its own activation energy. Encinar [15] have described this in detail. We used a similar formula and eq. (2) describes how the gas content (moles) changes with time.

$$
\ln \left(\frac{m_{0}}{m_{0}-m}\right)=k \times t,
$$

where $m_{0}$ represents the total gas content that has been generated after all possible pyrolysis of the residue has been completed, that is, when the residue is exhausted. $m$ and $k$ represents the number of moles generated and the gas generation rate constant at time $t$, respectively. Because the $\mathrm{CH}_{4}$ concentration is very small, the total amount produced is very low and the calculation of $\mathrm{CH}_{4}$ generated kinetic parameters is not required. Results of the $\mathrm{CO}$ and $\mathrm{CO}_{2}$ generation dynamic analysis are shown in Table 4.

The Arrhenius equation (eq. (3)) can then be used to determine the activation energy $\left(E_{\mathrm{a}}\right)$ and the results are shown in Table 5. Wheat straw and cotton stalk have similar activation energies for $\mathrm{CO}$ generation. The $\mathrm{CO}_{2}$ generation activation energy of wheat straw is slightly higher than that for the $\mathrm{CO}_{2}$ generation activation energy of cotton stalk. The activation energy indicates the degree of difficulty for a reaction to occur and the effects of temperature on the reaction rate. Larger activation energies indicate more difficult reactions and less temperature sensitivity.

$$
\ln k=\ln k_{0}-\frac{E_{\mathrm{a}}}{R} \times \frac{1}{T},
$$

where $k_{0}, E_{\mathrm{a}}, R, T$ represent the pre-exponential factor $\left(\mathrm{min}^{-1}\right)$, activation energy $\left(\mathrm{J} \mathrm{mol}^{-1}\right)$, gas constant and temperature $(\mathrm{K})$, respectively.

\section{Conclusions}

After torrefaction the products of cotton stalk and wheat straw are mainly solid products (charcoal), liquid products (water and tar) and gas products (mainly $\mathrm{CO}_{2}$ and $\mathrm{CO}$ ). With an increase in the torrefaction temperature, the quality yield of charcoal decreases significantly, the energy density increases and the energy yield decreases. The yield of liquid products and gas products increase as the temperature increases because of the decomposition of hemicellulose. The 

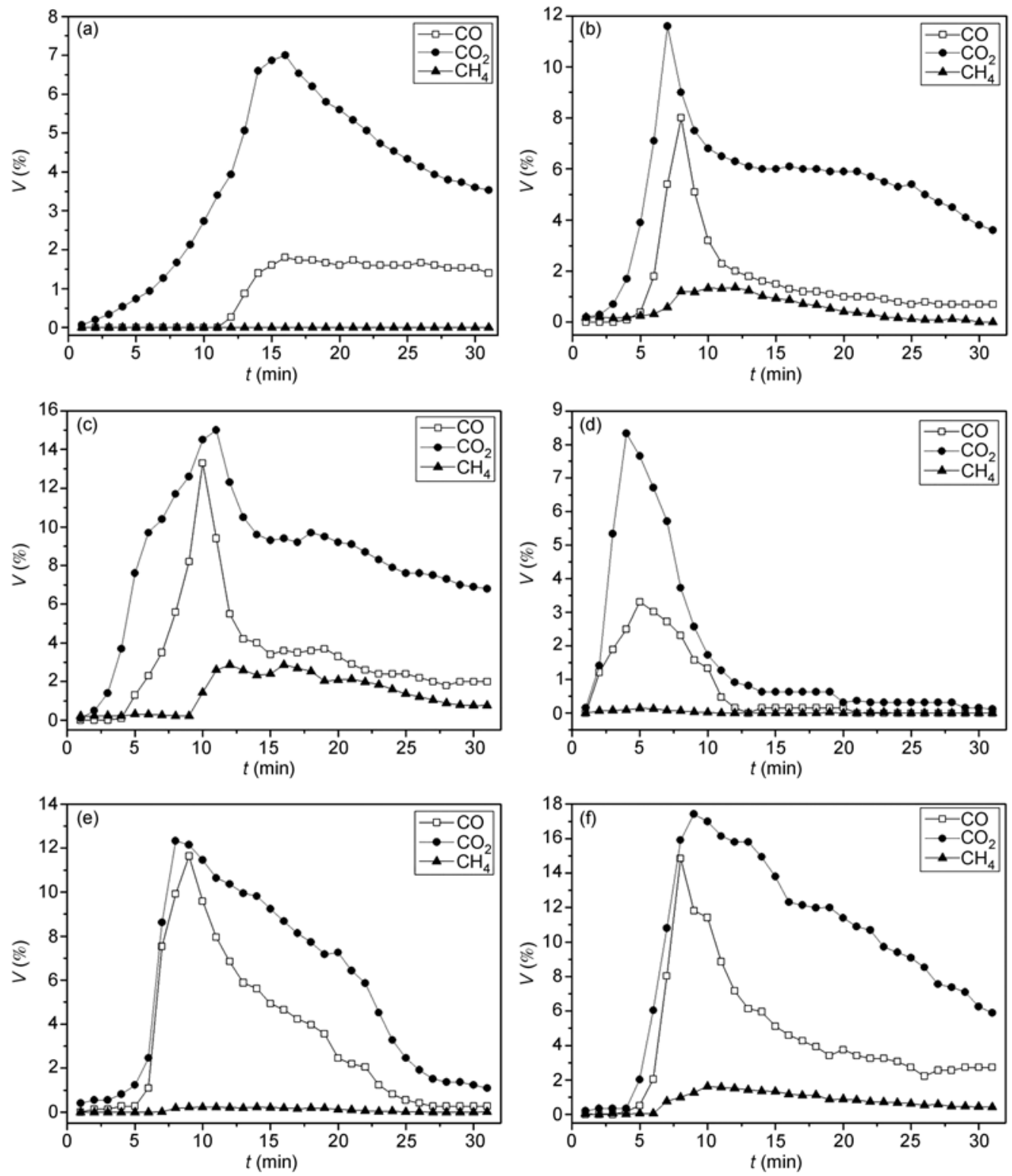

Figure 5 Concentration changes of gases during torrefaction. (a) Cotton stalk $200^{\circ} \mathrm{C}$; (b) cotton stalk $250^{\circ} \mathrm{C}$; (c) cotton stalk $300^{\circ} \mathrm{C}$; (d) wheat straw $200^{\circ} \mathrm{C}$; (e) wheat straw $250^{\circ} \mathrm{C}$; (f) wheat straw $300^{\circ} \mathrm{C}$.

Table 4 Rate constant of gas generation during biomass torrefaction

\begin{tabular}{cccc}
\hline \multirow{2}{*}{ Sample } & $\begin{array}{c}\text { Temperature } \\
\left({ }^{\circ} \mathrm{C}\right)\end{array}$ & \multicolumn{2}{c}{$K\left(10^{3} \mathrm{~min}^{-1}\right)$} \\
\cline { 3 - 4 } Cotton stalk & 200 & 48.68 & $\mathrm{CO}_{2}$ \\
& 250 & 71.18 & 31.60 \\
& 300 & 73.09 & 33.03 \\
\multirow{5}{*}{ Wheat straw } & 200 & 128.49 & 35.14 \\
& 250 & 178.48 & 141.72 \\
& 300 & 192.65 & 178.66 \\
\hline
\end{tabular}

apparent volume of the solid products decreases significantly and their grindability improves greatly with an increase in temperature. This reduces the cost of storage and
Table 5 Kinetic parameters of $\mathrm{CO}_{2}$ and $\mathrm{CO}$ generation during biomass torrefaction

\begin{tabular}{clccc}
\hline Sample & $\mathrm{Gas}$ & $\begin{array}{c}\text { Activation energy } \\
E_{\mathrm{a}}\left(\mathrm{kJ} \mathrm{mol}^{-1}\right)\end{array}$ & $\begin{array}{c}\text { Pre-exponential } \\
\text { factor } k_{0}\left(\mathrm{~min}^{-1}\right)\end{array}$ & $\begin{array}{c}\text { Correlation coef- } \\
\text { ficient }\left(R^{2}\right)\end{array}$ \\
\hline $\begin{array}{c}\text { Cotton } \\
\text { stalk }\end{array}$ & $\mathrm{CO}$ & 2.37 & 0.058 & 0.989 \\
Wheat & $\mathrm{CO}_{2}$ & 5.38 & 0.555 & 0.917 \\
straw & $\mathrm{CO}$ & 9.96 & 311.03 & 0.931 \\
\hline
\end{tabular}

transportation and also helps to reduce the required milling energy. Biomass torrefaction can be used as a pretreatment technology for briquettes, co-combustion with coal in boiler or co-gasification in an entrained flow gasifier. This method can improve the characteristics of the biomass therefore 
large-scale use of biomass can become feasible. Taking into account the energy yield, grindability and other factors, the experiment results reveal that the optimum torrefaction temperature is between $230^{\circ} \mathrm{C}$ and $250^{\circ} \mathrm{C}$, and the reaction time should be around $30 \mathrm{~min}$.

1 Arias B, Pevida C, Fermoso J, et al. Influence of torrefaction on the grindability and reactivity of woody biomass. Fuel Process Technol, 2008, 89: 169-175

2 Zhang W W, Zeng G Y, Chen X L, et al. Pretreament technology of biomass entrained flow gasification. Chinese J Process Engineer, 2007, 7: 747-750

3 Deng J, Wang G J, Kuang J H, et al. Pretreatment of agricultural residues for co-gasification via torrefaction. J Anal Appl Pyrolysis, 2009, 86: 331-337

4 Prins M J, Ptasinski K J, Janssen F J J G. Torrefaction of wood Part 1. Weight loss kinetics. J Anal Appl Pyrolysis, 2006, 77: 28-34

5 Prins M J, Ptasinski K J, Janssen F J J G. Torrefaction of wood Part 2. Analysis of products. J Anal Appl Pyrolysis, 2006, 77: 35-40

6 Prins M J, Ptasinski K J, Janssen F J J G. More efficient biomass gasification via torrefaction. Energy, 2006, 31: 3458-3470
7 Saravanakumar A, Haridasan T M, Bai R K. Technical and feasibility study of conversion of long-stick wood to charcoal in a partial combustion metal kiln. Energ Sustain Develop, 2006, 10: 17-25

8 Felfi F F, Luengo C A, Suárez J A, et al. Wood briquette torrefaction. Energ Sustain Develop, 2005, 9: 19-22

9 Felfi F F, Luengo C A, Suárez J A, et al. Torrefied briquettes: technical and economic feasibility and perspectives in the Brazilian market. Energ Sustain Develop, 2005, 9: 23-29

10 Jiang E C, He G S. Experimental reasearch on low temperature pyrolysis of biomass extrusion bar of rice husk and sawdust. Trans CASE, 2007, 23: 188-191

11 Zhao H, Zhou J S, Cao X W, et al. Torrefaction impact on biomass entrained flow gasification. Acta Energ Sol Sin, 2008, 29: 15781586

12 Fisher T, Hajaligol M, Waymack B, et al. Pyrolysis behavior and kinetics of biomass derived materials. J Anal Appl Pyrolysis, 2002, 62: 331-349

13 Bourgois J, Guyonnet R, Saint E, et al. Characterization and analysis of torrefied wood. Wood Sci Technol, 1988, 22: 143-155

14 Yang C Y, Yang X M, Lv X S, et al. Pyrolysis of straw obtained from stagewise treatment. Chinese J Process Engin, 2005, 5: 379-383

15 Encinar J M, Beltran F J, Bernalte A, et al. Pyrolysis of two agricultural residues: Olive and grape bagasse. Influence of particle size and temperature. Biomass Bioenerg, 1996, 11: 397-409

Open Access This article is distributed under the terms of the Creative Commons Attribution License which permits any use, distribution, and reproduction in any medium, provided the original author(s) and source are credited. 